\title{
Viewer's Preference Towards Television Media For Effectual Advertisements With Special Reference To Tamil Nadu Regional Tv Channels
}

*Dr. K. Pongiannan

\section{Abstract} https://dx.doi.org/10.33601/effulgence.rdias/v10/i1/2012/19-23

Television is the media where the audiences are huge which had led to the outgrowth of cable television and it has contributed a lot towards popularizing television. Beyond providing entertainment, television vastly increases both the availability of information about the different products and exposure to the uses and advantages of such products through the advertisements telecasted in the middle of the programmes. Channels are booming just like sky as the limit. If there a couple of channels, without cable or satellite television viewers would be forced to watch whatever came on the Television. But, with growing numbers of Channels, the viewers can choose from the available varieties of channels. When they prefer to watch a particular channel, the programmes and advertisements telecasted will reach the viewers more easily than the less preferred channels. Thus this study focuses on the viewer's preference towards television channels particularly regional channels in Tamil Nadu, for effective advertisements.

Key Words: Television, Media, Channel, Advertisements, Effectiveness, Viewers.

\section{INTRODUCTION}

$\mathrm{T}$ elevision has been called a 'plug-in-drug', keeping people glued to the screen and impeding the enjoyment of more valuable experiences. Television can be used to enhance many important aspects of everyday life. People seek entertainment and distraction, and Television can give us that in the form of films or cartoons. People want education, information and instruction because they are inquisitive and like to learn. Television gives us these in documentaries or educational programmes, in reports or cultural magazines. People enjoy creativity, and Television gives us that in the work of all the people involved in creating clever film scripts, effective scenery, witty dialogues or magnificent camera shots. Television gives us the world, other cultures, other people, languages and ideas. In addition, it gives awareness and description about the different products and services available in the market through advertisements.

Television is the media where the audiences are huge which had led to the outgrowth of cable television and it has contributed a lot towards popularizing television. Beyond providing entertainment, television vastly increases both the availability of information about the different products and exposure to the uses and advantages of such products through the advertisements telecasted in the middle of the programmes.

Channels are booming just like sky as the limit. If there a couple of channels, without cable or satellite television viewers would be forced to watch whatever came on the Television. But, with growing numbers of Channels, the viewers can choose from the available varieties of channels. When they prefer to watch a particular channel, the programmes and advertisements telecasted will reach the viewers more easily than the less preferred channels. Thus this study focuses on the viewer's preference towards television channels particularly regional channels in Tamil Nadu, for effective advertisements.

\section{SIGNIFICANCE OF THE STUDY}

There is severe competition among Regional television channel; some of them have become pay channel. The marketers as well as the advertisers advertise their products/services in all these channels. But, the effectiveness of such advertisements depends on its reachability and popularity of the channels among the viewers. However, very often the viewer's preference may 
vary from one channel to another and from one programme to another. Hence it initiated the researcher to study the viewer's preference towards Tamil regional television channels and also study the factors which influence the viewers to watch particular Television channel and Programme. Since Tamil is the Regional Language, this study confines to the Viewers preference towards Tamil Television Channels in Coimbatore.

\section{OBJECTIVES OF THE STUDY}

1. To examine the gender-wise preference of Tamil Television Channels.

2. To identify the most preferred regional Television channel for advertisements.

3. To examine the study variables such as core/related aspects, delivery of programmes, social responsibility and preference for a Television channel for viewing advertisements.

4. To study the factors that predicts the preference for a Television channel.

\section{RESEARCH METHODOLOGY}

To investigate the objectives a descriptive study using Primary data collection was followed. Data collected and analyzed by quantitative techniques. A Questionnaire was used as an instrument to collect the data. The data was collected from 150 respondents.

Sampling frame: The geographical area of Coimbatore city was chosen as the Universe. The main reason for choosing Coimbatore City is that the investigator is located here and is familiar with the place. In this study, the researcher has chosen the residents of Peelamedu in Coimbatore as the sampling unit. The dwelling units of Peelamedu were listed and arranged in sequential order. 451 dwelling units were identified. The questionnaire was administered at random by selecting every third of the dwelling units. 151 questionnaires were administered. The age groups of the respondents were not so emphasized; however, the data was collected from whoever was available at home. Accordingly 150 questionnaires were returned yielding a response rate of $99.33 \%$.

Techniques used for Analysis: The techniques used for analysis are Descriptive statistics, Multiple Regression, Mann-Whitney U test, and Chi-Square test. Multiple regression was used to study the factors predicting the preference for a TV channel. Chi-square and U-tests were used to examine the significant difference among the study variables. Friedman Two-way ANOVA was used to identify the preference of respondents on the TV channels. ANALYSIS AND INTERPRETATION

The data collected from the respondents was tabulated and analyzed using appropriate statistical techniques mentioned in the research methodology. The objective-wise analysis and interpretations are presented in the following sections.

\section{Analysis on the gender-wise preference for Tamil Television Channels:}

The gender wise preference for the TV channels is examined using mean ranks. The results are displayed in the Table 1. The test of significant difference is done using Mann Whitney U-test.

Table I shows that the mean rank for the preference of Sun TV among male and female viewers is 82 and 68.46 respectively. U-test statistic is 2301; $\mathrm{p}=0.052$ which indicates that preference of men and women on Sun TV is the same.

The table shows that the mean rank for the preference of Sun News among male and female viewers is 75.18 and 75.85 respectively. The U-test statistic is 278; $\mathrm{p}=0.925$ which implies that male and female equally prefer Sun news.

The table shows that the mean rank for the preference of Sun Music among male and female viewers 78.15 and 72.63 respectively. Further the insignificant U statistic (2601.50; $\mathrm{p}=0.435)$ indicates that the preference for sun music does not differ according to gender.

The table shows that the mean rank for the preference of Jaya TV among male and female viewers is 82.99 and 67.38 respectively. U-test statistic is 2223.5; $\mathrm{p}=0.027$ which depicts that male and female differently prefer Jaya TV. Also, Male prefer Jaya TV more than Female viewers.

Further, the mean rank for the preference of Star Vijay among male and female viewers is 79.56 and 71.10 respectively. U-test statistic is $2491.00 ; \mathrm{p}=0.230$ which portrays that males and females equally prefer Star Vijay.

Also, the Table I shows that the mean rank for the preference of Raj TV among male and female viewers is 77.12 and 73.75 respectively. U-test statistic is 2682.00; $\mathrm{p}=$ 0.634 which reveals that male and female viewers equally prefer Raj TV.

It can also be inferred from the Table I shows that the mean rank for the preference of Raj Digital TV among male and 
female viewers is 77.32 and 73.53 respectively. $U$-test statistic is 2666.00; $p=0.59$ which depicts that the viewers preference for Raj Digital TV does not differ based on gender.

Further, the table shows that the mean rank for the preference of K TV among male and female viewers is 73.51 and 77.66 respectively. U-test statistic is $2652.50 ; \mathrm{p}=0.557$ which indicates that male and female equally prefer KTV.

In addition, the table shows that the mean rank for the preference of Makkal TV among male and female viewers is 67.71 and 83.94 respectively. U-test statistic is 2200.50; $\mathrm{p}=$ 0.021 . It indicates that male and female viewers differently prefer MakkalTV.

Similalrly, the table shows that the mean rank for the preference of Chutti TV among male and female viewers is 74.12 and 76.99 respectively. U-test statistic is $2700.50 ; \mathrm{p}=$ 0.684 . It indicates that male and female viewers equally prefer ChuttiTV.

Further, the table shows that the mean rank for the preference of Tamilan TV among male and female viewers is 72.13 and 79.15 respectively. $\mathrm{U}$-test statistic is $2545.00 ; \mathrm{p}=0.318$. It indicates that male and female viewers equally prefer Tamilan TV.

The table shows that the mean rank for the preference of Polimer TV among male and female viewers is 73.60 and 77.56 respectively. Also, the Table I shows that the mean rank for the preference of UTV among male and female viewers is 71.69 and 79.63 respectively. U-test statistic is $2510.50 ; \mathrm{p}=0.259$ which indicates that male and female viewers equally prefer UTV.

Analysis on the respondents' most preferred Tamil TV channel for advertisements: To find the preference for channels to view advertisements, Two way ANOVA (Friedman) was used. The results of the tests are available in the table below

\section{Table 2 : Two-Way ANOVA on respondents' most preferred Tamil TV channel for viewing advertisements}

\section{TV Channels Mean Rank Chi-Square(Sig at 5\% level)}

$\begin{array}{lll}\text { Sun TV } & 3.46 & 139.23 \mathrm{P}=0.000 \mathrm{df}=11 \\ \text { Sun News } & 5.34 & \\ \text { Sun Music } & 5.35\end{array}$

$\begin{array}{ll}\text { Jaya TV } & 6.17 \\ \text { Star Vijay } & 5.59 \\ \text { Raj } & 6.78 \\ \text { Raj Digital } & 7.66 \\ \text { KTV } & 7.24 \\ \text { MakkalTV } & 8.35 \\ \text { ChuttiTV } & 9.06 \\ \text { Tamilan TV } & 9.03 \\ \text { Polimer } & 8.38 \\ \text { UTV } & 8.59\end{array}$

The Table 2 shows that Chi-square is significant at 0.05 level. Therefore, the preference for TV channels differs significantly. It is found that Sun TV is the most preferred channel followed by Sun News, Sun Music, Star Vijay, Jaya TV, Raj TV, K TV, Raj Digital, Makkal TV, Polimer TV, U TV, Tamilan TV and Chuti TV.

Analysis on the study variables core/related aspects, delivery, social responsibility and preference for a Television channel: To examine the study variables descriptive statistics was applied and the results are tabulated in Table 3.3.

Table 3 : Descriptive analysis on the factors influencing the preference for TV Channel

\begin{tabular}{|c|c|c|}
\hline Factors & Mean & Std. Deviation \\
\hline Core/related aspects & 3.42 & 0.51 \\
\hline Delivery & 3.47 & 0.54 \\
\hline Social responsibility & 3.45 & 0.58 \\
\hline $\begin{array}{l}\text { Preference towards the TV } \\
\text { channels for advertisements }\end{array}$ & 3.50 & 0.77 \\
\hline
\end{tabular}

The Table 3 shows that the mean score for the study variables. The mean for core/related aspects is 3.42; standard deviation 0.51 , standard deviation is 0.54 , for social responsibility the mean is 3.45 ; standard deviation 0.58 , and for preference towards the channel the mean is 3.50 and standard deviation is 0.77 . This implies that the various study factors deviate slightly from the preference for regional level TV channels for watching advertisements.

Analysis on the factors that predicts the preference for a TV channel for viewing advertisements: This objective aims to establish relationship between the dependent variable preference for a TV channel and the set of independent variables Core/related aspects, delivery, and social responsibility.

This objective is studied using Multiple Regression. The 
variable preference for a TV channel entered the regression model as dependent variable and the variables core/related aspects, delivery and social responsibility entered the model as independent variables. The regression results are displayed in the Table 4.

\section{Table 4 : Results of regression predicting the preference for a TV channel to view advertisements}

\begin{tabular}{lll} 
Variables & $\begin{array}{l}\text { Standardized } \\
\text { Coefficients }(\beta)\end{array}$ & Sig at 5\% level \\
& \multicolumn{2}{l}{} \\
Core / Related aspects & 0.141 & 0.209 \\
Delivery & $.0328^{*}$ & 0.011 \\
Social Responsibility & 0.184 & 0.080
\end{tabular}

$F=27.724 ; p=0.00{ }^{*}$ significant at 0.05 level

Multiple regression results in $\mathrm{R}^{2}=0.363$. This indicates the amount of variance explained by the independent variables on the dependent variable. On examination of the coefficient table, it is found that the variable delivery alone predicts the dependent variable at 0.05 level. The strength of relationship is indicated by the â value $(=0.328)$.

\section{FINDINGS OF THE STUDY}

The following are the major findings based on the analysis:

- The gender wise preferences for the TV channels were examined using mean ranks. The test of significance difference is tested using U-test. It indicates that preference of men and women on Sun TV, Sun News, Sun Music, Star Vijay, Raj TV, Raj Digital, K TV, Makkal TV, Chutti TV, and Tamilan TV is the same. But, the preference for Jaya TV is significantly different among male and female viewers. Male respondents prefer Jaya TV more than female respondents.

- To find the preference for channels to view advertisements, Two way Anova (Friedman) was used and it was found that Sun TV is the most preferred channel followed by Sun News, Sun Music, Star Vijay, Jaya TV, Raj TV, K TV, Raj Digital, Makkal TV, Polimer TV, U TV, Tamilan TV and Chutti TV.

- In order to the study the variable mean scores where given, it revealed that the factors of core/related aspects, delivery, social responsibility, preference towards the channel for viewing advertisements are slightly moving towards the agreement.

- On the examination of Coefficient table, it was found that the variable of delivery of programmes alone influences the results of the preference for a Tamil Television channel to view advertisements.

\section{IMPLICATIONS OF THE STUDY}

Based on the statistical analysis of the data and their major findings, the following are the implications which are proposed to the media owners for better performance of the Tamil TV channels:

- From the study it is strongly suggested that, advertisements should be telecasted in the middle of appropriate programmes to effectively reach the audience.

- $\quad$ Further, Sun TV being the most preferred regional level TV channel creates high reachability and popularity for the advertisements telecasted in it. Hence, it is suggested to telecast the advertisements mainly in Sun TV.

- It was opined by the viewers that the programmes in Television had affected their thoughts, culture and behaviour and hence steps may be taken by the concerned TV Channel to see that the programmes have a positive effect on viewers.

- Viewers of Tamil Television channel suggested to improve the quality of program by making them more informative.

- Most of the viewers have suggested that agriculturist and educational programmes should be included.

- It is suggested to give interesting interactive \& Live telecast programmes like creativity based programmes in order to avoid monotonous type of programmes.

- Majority of the viewers have suggested that Regional Television channels should telecast their programmes in proper appealing dress code by women and they should also have a professional appearance.

\section{CONCLUSION}

Today the Indian sky is overcrowded with many new satellite and regional channels having entered the scene with many new programmes. Each satellite and regional channels have made unique contribution to viewers and each stand out with uniqueness when compared to each other. In spite of the growth of satellite channels, the viewers still prefer some regional channels to view advertisements. This study reveals that viewers prefer regional channel for advertisements mainly due to programme delivery.

\section{REFERENCES}

\section{A) JOURNALS}

1. Dunn Watson.S, Barban Arnold.M, Television its role in 
modern Marketing, Hinsale, The Dryden Press, 1978, pg.574.

2. Gupta.K, Role of Television, Marketing and Management, Vol. VI, Issue II, April 1994, pg 170.

3. Kavitha Prasad, Television News channels in India, Indian Journal of Management, Vol.II, Issue.XI, pg.74.

4. Mohammed Adul Azem, Audience choice in different
Television Channel, Advertising and Management, Vol.XIII, Issue.IV, April 2001, pg.30.

5. Mukul Malhotra, Indian Journal of Telemarketing, Vol.VI, Issue VII, May 2005, pg. 65.

6. Nanda Kapoor, Television and Social messaging, Indian Marketing Management, May 2000, Vol. VIII, Issue.III, pg.29.

B) BOOKS

- Gupta.S.P, 1997 Statistical methods, New Delhi, Sultan Chand and Sons.

- $\quad$ Kothari.C.R, 1998, Research Methodology, New Delhi: Wihwa Prakashan.

- $\quad$ Philip Kotler \& Gray Armstrong, 2001, Principles of Marketing, $9^{\text {th }}$ Edition Prentice Hall of India, New Delhi.

Table 1 : Gender-wise preference for Tamil Television Channels

\begin{tabular}{|c|c|c|c|c|c|}
\hline Description & Gender & $\mathbf{N}$ & Mean Rank & Mann-Whitney U & $\mathrm{p}$ \\
\hline Sun TV & $\begin{array}{l}\text { Male } \\
\text { Female }\end{array}$ & $\begin{array}{l}78 \\
72\end{array}$ & $\begin{array}{l}82.00 \\
68.46\end{array}$ & 2301.00 & 0.052 \\
\hline Sun news & $\begin{array}{l}\text { Male } \\
\text { Female }\end{array}$ & $\begin{array}{l}78 \\
72\end{array}$ & $\begin{array}{l}75.18 \\
75.85\end{array}$ & 2783.00 & 0.925 \\
\hline Sun Music & $\begin{array}{l}\text { Male } \\
\text { Female }\end{array}$ & $\begin{array}{l}78 \\
72\end{array}$ & $\begin{array}{l}78.15 \\
72.63\end{array}$ & 2601.50 & 0.435 \\
\hline Jaya TV & $\begin{array}{l}\text { Male } \\
\text { Female }\end{array}$ & $\begin{array}{l}78 \\
72\end{array}$ & $\begin{array}{l}82.99 \\
67.38\end{array}$ & 2223.50 & 0.027 \\
\hline Raj & $\begin{array}{l}\text { Male } \\
\text { Female }\end{array}$ & $\begin{array}{l}78 \\
72\end{array}$ & $\begin{array}{l}77.12 \\
73.75\end{array}$ & 2682.00 & 0.634 \\
\hline Raj Digital & $\begin{array}{l}\text { Male } \\
\text { Female }\end{array}$ & $\begin{array}{l}78 \\
72\end{array}$ & $\begin{array}{l}77.32 \\
73.53\end{array}$ & 2666.00 & 0.591 \\
\hline K TV & $\begin{array}{l}\text { Male } \\
\text { Female }\end{array}$ & $\begin{array}{l}78 \\
72\end{array}$ & $\begin{array}{l}73.51 \\
77.66\end{array}$ & 2652.500 & 0.557 \\
\hline Makkal TV & $\begin{array}{l}\text { Male } \\
\text { Female }\end{array}$ & $\begin{array}{l}78 \\
72\end{array}$ & $\begin{array}{l}67.71 \\
83.94\end{array}$ & 2200.50 & 0.021 \\
\hline Chutti TV & $\begin{array}{l}\text { Male } \\
\text { Female }\end{array}$ & $\begin{array}{l}78 \\
72\end{array}$ & $\begin{array}{l}74.12 \\
76.99\end{array}$ & 2700.50 & 0.684 \\
\hline Tamilan TV & Male & 78 & 72.13 & 2545.00 & .318 \\
\hline
\end{tabular}

